\title{
The Standard of Proof for Redressing Wrongful Convictions - A Comparative Study with Case Analyses
}

\author{
He Jiahong ${ }^{1,2, *}$ \\ ${ }^{1}$ SJD, Northwestern University, USA \\ ${ }^{2}$ Deputy Director of the Research Center for Criminal Law, Law School, Renmin University of China
}

\begin{abstract}
Instances of wrongful conviction have the nature of universality and latency. The determination of wrongful conviction has the nature of ambiguousness and antagonism. The facts behind a case of wrongful conviction are not always black-and-white; sometimes there is a grey zone, meaning that there is no way to determine with accuracy whether the defendant is guilty or not. As a result, the rectification of wrongful conviction becomes very difficult. In the case of Hugejiletu, for example, although the true perpetrator came out in 2005, the wrongful conviction had not been corrected by the court until the end of 2014. Therefore, the standard of proof for redressing wrongful convictions needs to be clarified. Through case analyses of the standard in USA, UK and Germany, we can see that the standard for redressing wrongful convictions are different from the standard for convictions, with the former being generally lower than the latter. We should restate the standard of proof for redressing wrongful convictions in Chinese criminal proceedings, and make distinctions between the standard for starting a retrial, the standard for redressing a wrongful conviction, and the standard for awarding a state compensation.
\end{abstract}

Keywords: Chinese criminal proceeding, wrongful conviction, standard of proof, retrial, redressing.

We cannot see history, and some truths might be lost forever. We can only try to recover them with pieces of evidence. How to obtain and use the evidence constitutes procedural justice, without which the people will lose confidence in social justice.

He Jiahong, China Daily, 2015-04-30

Wrongful convictions are frequently covered up, easily concealed amidst the magnitude of correct verdicts. Some of dormant, or cold, cases do occasionally rise to the surface, gain the attention of law enforcement or the public, and so encounter an opportunity for rectification. In China, the cases of Teng Xingshan, She Xianglin and Zhao Zuohai, for example, were all exposed to the world when the alleged 'victim' came 'back from the dead'. Indeed, cases of wrongful conviction often lay dormant for long periods before they are discovered. As part of our Empirical Study on Wrongful Convictions in China, ${ }^{1}$ the research team gathered 55 sets of case materials from wrongful conviction cases in China that had the rulings overturned and which resulted in compensation issued

*Address correspondence to this author at 59 Zhongguancun Street, Haidian District, Beijing, 100872, China; Tel: 8610-82509436; Fax: 8610-82509252; E-mail: hjiahong@126.com

${ }^{1}$ See He Jiahong and He Ran: Empirical Studies of Wrongful Convictions in Mainland China, Volume 80, No. 4, University of Cincinnati Law Review, Summer 2012, pp. 1277-1292.

E-ISSN: 1929-4409/15 by the national government between 1995 and 2007 . Among these cases, one salient trait was clear: violation of the prescribed custody in 48 cases involving 60 people. The average custodial period was five years. The case with the most egregious example of this was that of Li Huawei of Liaoning Province, accused of premeditated murder and held in custody for sixteen years. The shortest time involved the case of Zhu Mingli of Sichuan Province, accused of rape and held in custody for 372 days. Five people had been in custody for over ten years, fifty persons between five and ten years, and twenty-five had been in custody fewer than five years. ${ }^{2}$

Determination of the true facts behind a case of wrongful conviction is not always a black-and-white process; sometimes there is a grey zone, meaning that there is no way to determine with accuracy whether the defendant is guilty or not. In other words, the line between good guys and bad guys is not clear-cut, but rather fuzzy, and vague. As a result, coming up with standards regarding the rectification of wrongful conviction becomes problematic. In what follows, I will discuss the standard for determining the facts leading to wrongful conviction cases. This discussion represents the level and degree of knowledge that law enforcement officials must bring to their roles within the judiciary. Using the method of comparative study based on some real case analyses, I hope to push forward the

\footnotetext{
${ }^{2}$ See Liu Pinxin, ed., Criminal Wrongful Conviction: Factors and Strategies, China Legal Publishing House (Beijing), 2009, pp. 364-7.
}

๑) 2015 Lifescience Global 
amending of the provisions about redressing wrongful convictions in Chinese Criminal Procedure Law and perfecting the related institutions and mechanism.

\section{THE AMBIGUOUSNESS OF FACTS AND THE ANTAGONISM BETWEEN PARTIES IN REDRESSING WRONGFUL CONVICTIONS}

Adjudication is a reverse mental activity, in that it uses evidence to prove the facts of past events. Likewise, wrongful conviction is frequently only apparent many years after the event, which means that discovery of the miscarriage of justice is a second reverse mental activity performed on a past mental activity. Given the passage of time and change of location, the difficulty of the mental work involved is understandable, even if there is new evidence or newly discovered evidence. Certainly, in some wrongful conviction cases newly discovered evidence is substantial, even ironclad, but in the majority of wrongful convictions, new evidence does not constitute 100 percent proof of guilt or innocence, and so add varying degrees of ambiguity or uncertainty. Let's see the case of Hugejiletu.

On 9 April 1996, in the Saihan District of Hohhot City, Inner Mongolia, a young woman was raped and murdered in a public restroom. A police investigation determined the suspect to be a man going by the surname of Hugejiletu, who had first reported the crime. A confession was obtained from him. The Hohhot Intermediate People's Court, relying mainly on this confession, sentenced Hugejiletu to death for the crimes of rape and murder; this sentence was approved by the Inner Mongolia Autonomous Region High People's Court. Hugejiletu, aged just eighteen, was executed on 10 June 1996. The whole proceedings were going so fast that there were only 62 days from investigation to execution!

We have no way to answer with certainty, because the evidence includes some material that helps his case, and other things that damage it. Even though there may be evidence to show his guilt, there is also evidence clearing him of guilt. This is what we mean by uncertainty surrounding a conviction. As far as law enforcement is concerned, the facts of a case that occurred in the past are like 'the moon in the water'. The moonlight has an objective existence, but what investigators see is the image reflected and refracted. The water here refers to the evidence. Without evidence, law-enforcement officials have no way of determining the facts, but facts determined through evidence do not necessarily correspond to the objective facts. When the water is murky or choppy, the action of refraction and reflection distorts the image, sometimes so much so that the resulting image of the moonlight is totally different that the reality. In the case of Hugejiletu, the water is turgid, which is to say, the evidence itself suffers from defects and uncertainty. First of all, there is no direct evidence to prove that he carried out the crimes. Second, the evidence is incomplete, and even features a mutually exclusive chain of evidence. Finally, there are many problems with the key pieces of evidence. However, the evidence does not eliminate the possibility that Hugejiletu is guilty of murder. Thus, there are two moonlight images in the water: in one, Hugejiletu is guilty, and in the other, he is not. Which one reflects the truth? We do not yet know.

It is human nature to pursue one's own interests and to try to avoid harm. It is instinctive to deny or cover up our mistakes. For this reason, those whose work leads to wrongful convictions frequently do not wish to admit to this; some will even go to great lengths to prevent the cases from being overturned. Thus, work on such cases becomes a struggle, both overt and covert, between two collective and competing interests, especially in China. Let's see the Hugejiletu case again.

In 2005 the alleged serial rapist-murderer, Zhao Zhihong, in prison for another crime confessed of his own accord that he had raped and murdered a young woman in a public restroom at the location in question. Given the time and the location, this must have been the crime for which Hugejiletu had been executed. According to an investigating officer of the Inner Mongolia Autonomous Region Public Security Bureau, during his trial, Zhao Zhihong related consistently four times - the details of raping and murdering the young woman in the Hohhot public restroom. Despite the passage of over ten years, Zhao remembered the location of the crime, the victim's height, facial and body characteristics, and the circumstances of her death, including the position the body; his memory was accurate. On 30 October 2005, Zhao led the police to the location of the crime. Even though the restroom had been demolished, Zhao was still able to point out its original position. In November 2006 Zhao went on trial before the Hohhot Intermediate People's Court, but charges raised by the prosecution did not include rapemurder relating to the 9 April incident. After the conclusion of the trial, Zhao released an 'Appeal for Redemption' from his detention centre, once again 
narrating details of the 1996 rape-murder. Zhao wrote: 'Since my arrest, having been educated by the government, I want to find the conscience of a real human being as my life comes to an end.' For this reason, he demanded that the courts re-examine the case, 'in order to allow me to face the end of my life without regret. ${ }^{3}$ The case soon generated much public attention. Hugejiletu's parents, who had always maintained their son's innocence, filed appeals and petitions with much greater intensity after hearing the news. However, six years passed, and the relevant agencies did not respond with any clear conclusions. It was said that officials associated with the case reasoned that: 'the evidence to overturn the conviction was insufficient,' and that there was no ironclad evidence of a wrongful conviction.

At the time, guilt could be determined based on the defendant's confession alone, but at present, a wrongful conviction could not be established with defendant testimony alone. At that time, there was no demand for ironclad evidence of guilt; now, this is required to overturn the conviction. It is an embarrassing predicament.

It is clear that 'insufficient evidence' was a pretext for not overturning the convictions of Hugejiletu, and that a much deeper factor of this decision was the relevant officials' fear of and even resistance towards the responsibility to investigate and uncover wrongful conviction.

On 19 November 2014, the High People's Court of Inner Mongolia made a decision to retry the case Hugejiletu. On 15 December 2014, the High Court declared Hugejiletu's innocence. After 18 years, the wrongful conviction was finally corrected. However, it was too late for Hugejiletu and his family.

In the course of determining wrongful conviction, both ambiguity and antagonism can be encountered; to overcome this, there should be a unified and clear standard of proof, else the determination would differ according to those involved, or to details of the event, the time or the place. Some wrongful convictions are determined with relative ease, unimpeded, while others are pushed forward step by painful step. Some people will use the excuse that the standard of proof is not clear, or else apply their own interpretation of the

\footnotetext{
${ }^{3}$ See 'A young man executed in a case of rape and murder; ten years later the true culprit confesses and seeks redemption', published 14 February 2007 on the Xinhua News website www.xinhuanet.com
}

standard to obstruct the determination and rectification of a wrongful conviction, leading to endless appeals and petitions. As a means of studying issues in standards of proof for redressing wrongful convictions in China, we first must examine such standards in other countries.

\section{CASE ANALYSES OF THE AMERICAN STANDARD OF PROOF}

With my limited research ability in English, I have not found a clear provision about the standard of proof for redressing a wrongful conviction in American laws. According to Mark Godsey, Professor of Law at the University of Cincinnati College of Law, the standards for determining wrongful conviction in the United States are not uniform, and generally depend on whether new evidence (such as DNA analysis) could lead to reasonable doubt. This is much less than a demand that evidence be sufficient to prove innocence; rather, it only requires the claimant to supply evidence that forms a reasonable doubt with regard to the perpetration of the original crime. This is the standard according to the law. In practice, courts are allowed the flexibility to raise the standard, which they do frequently. If the evidence proves reasonable doubt but does not meet the standard for 'preponderant evidence' (meaning able to prove that the prisoner has a more than 50 per cent chance of being innocent), the courts will rule that 'it has not formed a reasonable doubt'. In this we can see that the standard according to the law and the standard applied in reality manifest some difference. Moreover, even if a prisoner appealed successfully, he would have won only the right to a retrial. If the evidence of innocence is strong (as in high-certainty DNA analysis), then the prosecution would generally forego a retrial and the prisoner may be declared innocent. But if the evidence is weak or uncertain the prosecution may decide to hold a second trial by jury. If the jury at this second trial issued a verdict of not guilty, the prisoner would be declared innocent. If the jury issued a guilty verdict, then he must be declared guilty. ${ }^{4}$

The standard for determining a wrongful conviction in the USA is generally 'the formation of reasonable doubt', but the standard held by the courts in practice is generally one demanding 'preponderant evidence'. Whether it is the standard of the law or the standard held in fact, both are perceptibly lower than the

${ }^{4}$ Professor Godsey is Director of the Ohio Innocence Project. The statement quoted above comes from his answers to the question of this author regarding to the standard for determining a wrongful conviction in the USA in July 2010. 
standard of criminal proceedings, which must prove the defendant guilty 'beyond reasonable doubt'. If based on new evidence the court determines the original verdict to have been a wrongful conviction, they may cancel the original verdict and immediately release the person in custody. This does not certify 'with finality' that the claimant is innocent. If the prosecution believes that a jury might find the claimant guilty despite the existence of new evidence, they can begin new prosecution proceedings. Because this would be a new trial after the cancellation of the original verdict, it does not violate the concept of 'double jeopardy'. In this second trial, if the jury found the defendant guilty in light of all the evidence - both new and old - the court would once again issue a sentence of guilt. If the jury found the defendant not guilty, the defendant would be declared innocent 'with finality'. In practice, cases in which the prosecution begins new proceedings are rare, especially when analysis of DNA evidence certifies the claimant to be not guilty.

\section{The Case of Robert McClendon}

On 25 April 1990 a ten-year-old girl was kidnapped from the back yard of her own home in Columbus, Ohio, taken to an empty residence nearby, and raped. The victim's parents learned of the incident the next day, took her to the hospital for an examination and reported the crime. Based on the victim's statement and her positive identification of her assailant, police arrested thirty-two-year-old Robert McClendon. Crimelab analysts failed to identify the presence of semen from the victim's underwear on the swabs collected from the hospital. Nevertheless, on 21 May prosecutors issued formal charges against Robert McClendon for the crimes of kidnapping and rape. On 26 August 1991, trial proceedings began in the county court. Since McClendon waved his right to a trial by jury, the case was heard by a sole presiding judge, David L. Johnson.

The evidence for the prosecution included photographs were taken at the crime scene, testimony by the victim's mother and the report of the hospital examination; however, the evidence that formally tied the accused to the crimes of kidnapping and murder were the statement and positive identification by the victim, as well as the defendant's poor performance in a lie-detection test. ${ }^{5}$ McClendon maintained his

\footnotetext{
${ }^{5}$ On 4 February 1991, McClendon agreed to the suggestion of the prosecution that he should undergo a lie-detection test, and further that the results of the test could be admitted as evidence in court. The test was administered by a specialist for the Ohio Highway Patrol, who noted in the results that McClendon "might possibly have deliberately lied" in his answers to relevant questions.
}

innocence. After just two days of trial, Judge Johnson found the defendant guilty of kidnapping and rape and sentenced him to life in prison, stipulating that he serve a minimum of fifteen years before becoming eligible for parole. McClendon filed an appeal, but the appeals court upheld the original verdict.

On 13 October 2004, McClendon requested that the DNA evidence be analysed again, but he was not granted his request. In April 2008 the Ohio Innocence Project represented McClendon's second request, which was granted. On 16 July DNA analysis experts determined that there were indeed traces of semen in the victim's underwear but that it could not have been McClendon's. On 11 August Judge Schneider announced the cancellation of the original verdict. Because the prosecution had already announced that it would not pursue new prosecution proceedings, but would rather use the DNA evidence to seek the true perpetrator, Robert McClendon, aged fifty-two and wrongfully held in custody for seventeen years, was released from prison and exonerated. ${ }^{6}$

\section{The Case of Joseph Abbitt}

Early in the morning of 2 May 1991, two girls aged thirteen and sixteen were tied up and raped in their own home in Winston-Salem County, North Carolina. One of the girls subsequently reported the crime and claimed their assailant had been a Joseph Abbitt, who had lived in the area and done odd jobs at the girls' home. When the police showed the girls a mixed photograph line-up, they identified Abbitt. Since Abbitt had left North Carolina, a wanted bulletin was issued for his arrest. In October 1994, Abbitt was arrested at a dog-walking park in Texas and transported to North Carolina for trial on the charges of burglary, kidnapping and rape. In June 1995, the Winston-Salem County Court formed a jury and opened trial proceedings. The main evidence for the prosecution was the statements of the two victims and their identification of Abbitt during court proceedings. Despite collection of material evidence, including the underwear and bed sheets of the victims from the scene of the crime as well as the positive identification of semen traces, the results of DNA analysis had been inconclusive, and could only show that the semen might have been Abbitt's. The

\footnotetext{
${ }^{6}$ According to Professor Godsey the prosecution later found the actual perpetrator of the crime by searching a nation-wide digital DNA evidence archive, but since the victim did not want to be involved the prosecutor was not able to file any new proceedings. This case narrative is based on an account in the article headlined, 'Hello freedom', published in The Columbus Dispatch, 12 August 2008.
} 
jury found Abbitt guilty, and he was sentenced to two life sentences plus an additional 110 years. Abbitt appealed unsuccessfully.

In 2005, the North Carolina Center on Actual Innocence appealed on Abbitt's behalf and was granted permission to have the DNA evidence reanalysed. They obtained material evidence, including the underwear of the victims; however, the conclusion from the first 're-analysis' was not strong enough to either exonerate or condemn. The experts were asked to attempt a second analysis using more accurate methods, and from this obtained conclusive proof that the semen samples were not from Abbitt. Progress was especially slow in the case, which dragged on until 2 September 2009, when Abbitt at last obtained a ruling that cancelled his original verdict. By then, he had been imprisoned for fourteen years. ${ }^{7}$

The McCLendon and Abbitt cases both involved the charge of rape, as well as statements and identification of the accused by child victims. Because the victims in both cases knew their alleged perpetrators, their 'identification' was based more on perception and memory from before the crime and was not in fact perception or memory of the crime itself. One scholar in the USA has pointed out that a major factor leading to a wrongful conviction in the USA is a misidentification of the accused by victims or eyewitnesses. ${ }^{8}$ Among the 242 cases of wrongful conviction, which as mentioned before were discovered through DNA evidence analysis, mistaken identification occurred 75 percent of the time. ${ }^{9}$ This is likely related to the type of case most often re-examined by The Innocence Project: many of them involve those who have been convicted of rape, and rape convictions very often take as their main evidence victim and eyewitness testimony. ${ }^{10}$ Despite the fact that in one of these cases a verdict was issued by a judge and the other from a jury, in both cases the unreliable testimony of the victims became the major basis of the guilty verdict.

\footnotetext{
${ }^{7} \mathrm{An}$ account of this case is found on the 'Know the Cases' section on the Innocence Project website www.innocenceproject.org/know.

${ }^{8}$ Thompson S. G. "Beyond a Reasonable Doubt? Reconsidering uncorroborated eyewitness identification testimony," UC Davis Law Review, 41: 1487-545 (2008).

${ }^{9}$ This data comes from the website of the Innocence Project, on the column entitled "Eyewitness Identification Reform." www.innocenceproject.org/fix/ Eyewitness-Identification.

${ }^{10}$ Because wrongful criminal conviction determination reveals slips in the system of identification, the American states are constantly improving the rules for identification, as in the establishment of "double blind" identification rules, meaning the person organizing the identification activity also does not know which person in the lineup is the suspect; also, the person making the identification is informed that the perpetrator of the crime may not be among those in the lineup.
}

In both cases, the determination of wrongful conviction relied on the high-certainty analysis of DNA evidence. Given the problems of long-term management of material evidence, as well as the nature of the relation between semen traces and rape, DNA re-analysis, even after a long hiatus as in the cases of McClendon and Abbitt, cannot absolutely exclude that the claimants committed the crime. It does not necessarily establish a reasonable doubt that the claimant is not guilty, but it certainly meets the standard for preponderant evidence that the claimant is not guilty.

\section{CASE ANALYSES OF THE BRITISH STANDARD OF PROOF}

The legal systems of the UK and the USA are largely similar, in particular, their standards of proof required for the determination of a wrongful conviction; however, in the UK the process of rectifying a wrongful conviction in the UK is separated into several stages, each of them with different standards of proof. The claimants applying for rectification of a wrongful conviction must first undergo examination by the Criminal Cases Review Commission. The standard for whether the Review Commission will refer the case to the appeals court for re-trial is if there is 'a true possibility of overturning the original verdict. ${ }^{, 11}$

If the appeals court accepts the case sent up from the Review Commission, it will conduct a new trial. Although the relevant laws do not clearly state any standard for proving a wrongful conviction in the new trial, based on the decisions of the appeals court where original verdicts were successfully cancelled ('The Guildford Four' - 1990, 'The Birmingham Six' - 1991, Judith Ward - 1992 and Carl Bridgewater - 1997), we can affirm that the standard for determining a wrongful conviction is the introduction of new evidence or evidence of new discoveries sufficient to the establishment of reasonable doubt of the guilty verdict and to overturning the original conviction. ${ }^{12}$

The UK issues 'state compensation' to victims of wrongful conviction but the determination of wrongful conviction in an appeals court does not automatically guarantee compensation. The party involved must still apply to the courts for compensation, and if the finding is that compensation is merited, such compensation

\footnotetext{
${ }^{11}$ See McConville, Mike and Geoffrey Wilson, English criminal justice process, translated by Yao Yongji, the Law Press (Beijing), 2003, 464-7.

${ }^{12}$ Ibid., pp. 459-61.
} 
would be awarded through the Ministry of Justice. Otherwise, no compensation is awarded. The standard for proving that compensation is merited is higher than that required to determine a wrongful conviction. The British government's 2004 standard of proving that compensation is merited was that the applicant must be able to prove beyond a reasonable doubt that he is innocent. However, the UK Supreme Court recently lowered the standard for proving compensation merit. ${ }^{13}$ It was the murder case of Raymond McCartney and Eamonn MacDermott that gave rise to this change in policy.

In 1977 the Royal Ulster Constabulary (RUC) detective constable Patrick McNulty was shot dead allegedly by members of the Irish Republican Army (IRA). A week later Jeffery Agate, Managing Director of the DuPont factory, was also shot dead, allegedly also by members of the IRA. Police identified Raymond McCartney and Eamonn MacDermott as suspects in the murders and used 'special interrogation methods' to elicit confessions from the two suspects. In 1979, McCartney and MacDermott were tried for murder in the Criminal Court of Northern Ireland, all the while maintaining their innocence, protesting that their confessions had been extorted. The defence brought forward other witnesses whose testimony related to their own experiences of torture at the hands of police, but the courts did not admit this to be used as evidence. McCartney and MacDermott were convicted of murdering of Patrick McNulty based largely on their confessions. McCartney was also convicted of murdering Jeffrey Agate. The two men were sentenced separately to life in prison. McCartney and MacDermott challenged the decisions and filed appeals, which were rejected by the Appeals Court of Northern Ireland in September 1982. MacDermott was released on parole after having served fifteen years in prison, after which he worked as a journalist. McCartney was released after serving seventeen years, became a commander of the IRA and participated in a fifty-three-day hunger strike. Later, he became a member of Sinn Fein. The two men have steadfastly maintained their innocence and that their confessions had been false and illegally obtained. After their release, they continued to file

\footnotetext{
${ }^{13}$ In October 2009, the Supreme Court of the United Kingdom was established, replacing the House of Lords Committee as Britain's final court of appeal and independent of both Parliament and other law enforcement agencies. The UK Supreme Court consisted of twelve judges. For civil suits, the Supreme Court accepts appeals from all regions within the United Kingdom; for criminal cases, it accepts cases from England, Wales, and Northern Ireland (but not Scotland). The conditions for accepting a case are generally controversial legal issues important to the public interest.
}

appeals in an effort to clear their names. Eventually, they obtained new evidence to support their claims and in September 2006 the UK Criminal Cases Review Commission found the probability that the two claimants had been subject to torture to be high, and so referred the case to the appeals court for retrial. The appeals court finally issued a ruling in February 2007, cancelling both guilty verdicts. The judges remarked that in light of the new evidence 'doubts existed regarding the surety of the guilty verdicts.' After the ruling was announced McCartney was quoted as saying: 'When we talk about these matters, we must consider the interrogation methods used by the UAR, and we must see how the court just wanted to put IRA members in jail with oral testimony alone. ${ }^{.14}$

After they had been exonerated McCartney and MacDermott applied for compensation. In 2008, the Court of Northern Ireland accepted their application but ruled that the evidence supplied failed to prove their innocence beyond a reasonable doubt, and so the two of them would not receive government compensation. They appealed to the Supreme Court, which on 11 May 2011 issued their ruling with a vote of five to four: McCartney and MacDermot would receive compensation. In their ruling, the Supreme Court also established a new standard for compensation, lowering it from 'proving innocence beyond a reasonable doubt' to 'new evidence sufficient to deny a guilty verdict'. The judges pointed out: 'If new or newly-discovered facts conclusively show that evidence used in charges against the defendant have been overturned, and to such an extent that a guilty verdict would not be forthcoming based on the evidence,' then this indicates a wrongful conviction under the law, with compensation due. The Chief Justice of the Supreme Court, Lord Nicholas Phillips, added that although the new standard would not ensure that only the truly innocent would receive compensation, 'it would, however, ensure that innocent defendants whose evidence of guilt had been overturned would not be denied compensation because they could not prove their own innocence beyond a reasonable doubt', meaning that the new standard 'possessed practicality under realistic conditions'. Justice Hope added: 'In their case, we cannot say that these newly discovered facts conclusively show that they are innocent, but we can say that, based on these newly discovered facts, the evidence used to charge them has been overturned,

\footnotetext{
${ }^{14}$ Based on the February 15, 2007 BBC News Report, "Murder convictions ruled unsafe."
} 
and to such an extent that the evidence is now insufficient to return a guilty verdict again. ${ }^{15}$

After the ruling was announced, a spokesperson for the Ministry of Justice, who as previously noted pays out the compensation, announced:

We welcome the ruling to reject Adams' request and affirm the rightness of the decision not to apply compensation. This was a lengthy and complex decision requiring some time to read thoroughly. Although the court has established new standards for wrongful conviction, we hope that compensation for wrongful conviction will still be applied only in the minimum number of cases. ${ }^{16}$

Public reaction to the new standards established by the ruling was also mixed. Some felt the new standards be too low, as the words above from the Ministry of Justice indicate. Some felt that the standards to be still not low enough. BBC reporter Danny Shaw, for example, pointed out that between 2009 and 2010 the number of wrongful conviction compensations was extremely low: on average, only one in thirty-seven claimants won compensation. This was because the standards for wrongful conviction compensation established by the Labour Party (proof beyond reasonable doubt) were too high. The Supreme Court's ruling effectively announced that the standards for proof were not appropriate, but it was thought by many that the newly established standards (that with new evidence a guilty verdict would not be forthcoming) were also high. An appeals court might, when cancelling a guilty verdict, rule the present evidence insufficient for a retrial. Under such circumstances, the claimant must prove in the application for compensation that the present evidence could not possibly lead to a guilty verdict, which is an extremely difficult case to make. For example, Barry George, who was found guilty of murder in 2000 , had his guilty

\footnotetext{
${ }^{15}$ The Supreme Court examined the cases of McCartney and MacDermott and of another claimant, Andrew Adams at the same time, but unanimously rejected the request made by Adams, noting that a reasonable jury might still convict Adams even with the new evidence. Adams, who had been declared guilty in 1993 of murdering retired teacher Jack Royal, had by served fourteen years of his sentence by 2007, when an appeals court cancelled his guilty verdict and declared him not guilty. He applied for government compensation. His application was rejected by a high court, but he appealed and the application was examined by the Supreme Court. See, 'UK court sets new standard on compensation for wrongful convictions', Associated Press, 11 May 2011. See also, 'Two men jailed for murder can seek compensation', The Irish Times, 12 May 2011.

${ }^{16}$ See 'Supreme Court allows miscarriage of justice appeals', BBC News, 11 May 2011.
}

verdict cancelled in 2008 by the appeals, which then indicated that the evidence in the case merited retrial. Even if George were acquitted by a jury in the subsequent retrial, it would be difficult for him to win compensation. Thus, if the Supreme Court had opened the door to compensation, it was only by a small crack. ${ }^{17}$

In summary, the standards for proving wrongful conviction in the UK involve three levels: first the standard by which the Criminal Cases Review Commission refers the case to the appeals court, the 'real possibility for overturning the original verdict'. Second, the standard by which the appeals court will overturn the original verdict is that 'new evidence is sufficient to establish reasonable doubt of the guilty verdict'. And third, the standard for issuing state compensation for wrongful conviction is that 'the evidence [including any new evidence] cannot possibly lead once again to a guilty verdict'. Whether the enacting of these standards is reasonable is not a question the author will address here, but I do believe that the UK system of separating the standards into these different levels is one that we Chinese can learn from.

\section{CASE ANALYSES OF THE GERMAN STANDARD OF PROOF}

In Germany Karl Peters (1904-98) well deserves recognition as the greatest champion of research into wrongful conviction. His book Fehlerquellen im Strafprozess: Eine Untersuchung der Wiederaufnahmeverfahren in der Bundesrepublik Deutschland, first published in the 1970s, is the most authoritative work on the subject. ${ }^{18}$ It is divided into three volumes: Introduction and Survey of Types of Cases; Sources of Error in the Judicial System: Research and Conclusions; and Sources of Error in the Judicial System: Retrial Procedure. The objects of his research were 1,150 cases of criminal wrongful conviction overturned in retrials in the German courts between 1951 and 1964. Among them, ninety-one were retrials ordered by the prosecution, and could be termed cases of 'wrongful release' or 'light punishment'. The other 1,059 cases were retrials upon application by the defendant, and could be termed cases of 'wrongful conviction' or 'heavy punishment'. Professor Peters maintains that verdicts overturned were not necessarily

\footnotetext{
${ }^{17}$ Ibid.

${ }^{18}$ English translation of this book title is: Sources of Errors in Criminal Proceedings: A Study of Cases of Successful Petitions of Revision in the Federal Republic of Germany.
} 
wrongful, because there is a spectrum of uncertainty between definitely guilty and definitely not guilty. In other words, the defendant might be guilty and might not be guilty. Professor Peters delineates the verdict determinations of the retrial into five types: the original verdict is definitely wrongful; the original verdict might possibly be wrongful; the original verdict cannot be proven fully; the original verdict might be correct; and, the original verdict is most likely correct. According to Professor Peters, in the first three circumstances the judge presiding at the retrial should find the verdict wrongful, while in the last two cases, even though the judge cannot find with certainty that the verdict was wrongful, a ruling should be produced that is favourable to the defendant. ${ }^{19}$

Professor Peters' views are instructive to our study of problems relating to standards of proof in cases of wrongful conviction. For ease of discussion, we can use hypothetical to show the standards by which wrongful conviction is determined based on comprehensive review of the evidence. In cases of the first type, the rate of finding the conviction wrongful is 100 percent; among type two, the rate is 80 percent; among type three, 60 percent; among type four, 40 percent, and among type 5, 20 percent. Professor Peters advocates that the first three types should be determined as wrongful. That is to say, the lowest rate of determination should be 60 percent. The "standard for proving the conviction to be wrongful" in these circumstances refers to this lowest level for proving the decision had been erroneous. Professor Peters posited that in types four and five, even though a mistaken verdict cannot be determined, a ruling should be issued in favour of the defendant. This accords with the German criminal procedure principle of in dubio pro reo: if the court cannot issue a definite ruling on the facts of a case based the evidence in toto - in other words, if there be any doubt - the ruling must be in favour of the defendant. What follows is an example of this in Germany's recent history:

Early in the morning on 29 April 1997, in Karlsruhe, a city in Baden-Württemberg, police officer Andrea Zacher was bound by the neck with a scarf and left in a position so that she was deprived of oxygen. Zacher survived but was brain-

\footnotetext{
${ }^{19}$ In the summer of 2010 , this author travelled to Germany to serve as a visiting scholar at the Max Planck Institute for Foreign and International Criminal Law. While there, I spoke with German scholars and judges to learn about the state of wrongful conviction cases in Germany. These texts were translated by Zhou Zunyou, a doctoral student then at the Max Planck Institute.
}

dead. Her father, who had found her, rang the police immediately.

Investigators discovered no traces of forced entry but did collect two fingerprints from a pair of latex gloves, as well as a plastic bag containing a scarf, gloves and cigarettes. According to the victim's father, police focused on two suspects. First, Harry Wörz, Zacher's husband of three years and the father of her child. The couple was involved in divorce proceedings. The other suspect was Thomas Hein, a colleague and Zacher's lover. Hein was also married, and his wife testified that he had spent the entire evening with her and so could not have been at the scene of the crime. Based on this, police removed Hein from the list of suspects. DNA evaluation by crime-lab analysts determined that the fingerprints on the latex gloves belonged to Wörz. Additionally, police determined that the contents of the plastic bag belonged to him. On 16 January 1998 and after a trial, the Karlsruhe Regional Court sentenced Wörz to eleven years in prison for attempted murder. The defendant refused to accept the verdict and appealed. That August the Federal Appeals Court rejected the application and upheld the original decision.

After the sentence had gone into effect, Worz's parents filed a civil suit for compensation. The Karlsruhe Regional Civil Court examined the case without influence from the criminal proceedings and on 5 April 2001, the judge ruled that the evidence was insufficient to prove without doubt that the Wörz was indeed guilty. The judge commented on the fact that the defendant had willingly submitted to a lie-detection test that had corroborated his claim of innocence. Wörz subsequently and successfully appealed to the Supreme Court for a retrial in the criminal court. On 6 October 2005 the Mannheim Criminal Court issued its ruling to cancel the original verdict on the grounds of insufficient evidence to prove guilt beyond a reasonable doubt. Worz was declared not guilty.

The Mannheim prosecutor's office and the victim's family filed an appeal with the Federal Court, it was accepted, and on 16 October 2006, a ruling was issued to cancel the previous verdict on the basis of legal errors found in the determination. The case was sent for retrial once again. On 22 October 2009, the judge of the Mannheim Regional Court once more declared the Wörz not guilty by reason of insufficient evidence. ${ }^{20}$

\footnotetext{
${ }^{20}$ See Zhou Zunyou, 'How does Germany rectify wrongful conviction?' Evidence Law Forum, issue 16, Law Press (Beijing), 2011, 240-69.
} 
German criminal procedure applies the principle of 'free proof with intimate conviction', meaning that the law has no specific rules regarding the evaluation of evidence and the standards of proof, but rather a requirement that the judge determining guilt reaches a point of 'intimate conviction'. We may call this the 'intimate conviction' standard of proof. Correspondingly, whenever the judge is unable to come to a point of 'intimate conviction' about the values of all the evidence, and then he or she must determine the original guilty verdict to have been wrongful. In other words, the German standard for proving a wrongful conviction can be expressed as an 'overturning intimate conviction' standard. In the Wörz case, the Mannheim Regional Court's not-guilty verdict exemplifies this concept. Strictly speaking, the evidence in hand was far from sufficient to preclude any possibility that Wörz was the perpetrator. And regardless of the fact that the judge thought Hein should have remained a suspect, and thought also that his wife had given false testimony, there was still drastically insufficient evidence to prove Hein's guilt or innocence. Under these circumstances, since the court could not reach 'intimate conviction' about the guilt of Wörz, it was required to cancel the original verdict, and declare Wörz not guilty. This shows that, even though the principle of 'free proof with intimate conviction' entrusts the judge with discretionary powers, the standard for proving wrongful conviction is clearly lower than that for proving guilt.

\section{THE ANALYSIS AND RESTATEMENT OF CHINESE STANDARD FOR PROVING WRONGFUL CONVICTION}

The Chinese law lacks clear-cut standards for proving wrongful conviction, but does stipulate the conditions for enacting a retrial. And since retrial is the first step towards redressing wrongful conviction, criteria for retrial and standards for proving wrongful conviction are closely connected. The 2012 revision of the Criminal Procedure Law, Article 242, states:

If a petition presented by a party or his legal representative or his near relative conforms to any of the following conditions, the people's court shall retry the case: (1) There is new evidence to prove that the confirmation of the facts in the original judgment or ruling is definitely wrong; (2) The evidence upon which the conviction was made and the punishment was meted out is unreliable or insufficient, or should be excluded according to law, or the major pieces of evidence for proving the facts in the case contradict each other; (3) The application of law in making the original judgment or ruling is definitely incorrect; or (4) The judges in trying the case committed acts of embezzlement, bribery, or malpractices for personal gain, or bent the law in making judgment.

Article 243 states: If the president of a People's Court at any level finds some definite error in a legally effective judgment or ruling of his court as to the determination of facts or application of law, he shall refer the case to the trial committee for deliberation.' Paragraphs two and three of this article also use the term 'definite error'. According to the rules stipulated here, standards for proving wrongful conviction have been interpreted to be standards of 'definite error'.

Before discussing these standards further, I first want to explain the method of proving wrongful conviction in China. Based on the different ways wrongful conviction is discovered and proved, we can classify the methods for proving wrongful conviction into two types: direct proof and indirect proof.

The first method means using evidence to prove that the accused did not commit the criminal act for which they had been convicted. This situation is common to cases where the alleged victims have 'come back from the dead', as in the case of She Xianglin ${ }^{21}$ and to instances where major evidence from the original trial has been re-examined and subsequently rejected, as with the American Innocence Project.

The second type (indirect) includes methods for counter-proof, meaning proof that another person has

\footnotetext{
${ }^{21}$ On 11 April 1994, a badly decomposed body was discovered in an irrigation tank in Jingshan County, Jingzhou Prefecture, Hubei Province. Investigators determined that the body was of Zhang Zaiyu, a local villager who had been missing for three months. Her husband She Xianglin was identified as a suspect, and a confession of guilt was obtained. On 22 September, the procuratorate issued an indictment. On 13 October, the Jingzhou Prefecture Intermediate People's Court found She guilty and sentenced him to death. On 6 January 1995, the Hubei Provincial High People's Court declared this verdict invalid by reason of "facts unclear, evidence insufficient," ordering a retrial. On 15 June 1998, after a change in the jurisidiction, the Jingshan County People's Court found She guilty again and sentenced him to 15 years' imprisonment. On 22 September, the Jingmen Municipal Intermediate People's Court rejected his appeal and upheld this decision. On 28 March 2005, She Xianglin's wife presumed dead for over 11 years, "returned to life." On 1 April, She Xianglin was released from Prison. On 13 April, the Jingshan County Court retried She and found him not guilty. See the story of She Xianglin case, Back from the Dead, written by $\mathrm{He}$ Jiahong, and published by Penguin as an e-book in English in February, 2014
} 
committed the crime thus indirectly proves the defendant from the original trial to be not guilty. This situation is common to cases where a suspect or defendant in another case confesses that he is the true perpetrator in the original case, as in the case of Hugejiletu, and when evidence prove the existence and guilt of true perpetrator, as in the case of Shi Dongyu. ${ }^{22}$ It is also common to cases where new evidence comes to light and which indicates clearly an error in the original verdict, as in the case of Du Peiwu. ${ }^{23}$ Such scenarios occur also in combination.

In some cases, proof of wrongful conviction may be ironclad, as with the case of She Xianglin. Not every case must achieve such a high standard. The 'definite error' rule is sometimes interpreted to mean equal to the standard that demands 'clear facts in the case, with full and reliable evidence' to issue a guilty verdict, with the result that the accused is often required to provide evidence full and reliable enough to prove their innocence, or else full and reliable enough to prove that another person is the true perpetrator. This interpretation is mistaken, or at least inappropriate. Let's see another case which is similar to the case of Hugejiletu.

At around 5 p.m. on 5 August 1994, a woman by the surname of Kang, who worked at a hydraulic parts factory in Shijiazhuang, Hebei province, was raped and murdered in a cornfield by the side of a road on the

\footnotetext{
${ }^{22}$ On 5 April 1989, a murder was committed in a forest farm in China's northeast, Yichun City in Heilongjiang Province. Shi Dongyu was identified as a suspect in the crime. On 5 April 1991, the Yichun Municipal Intermediate People's Court sentenced Shi Dongyu to death for the crime of murder, and the sentence should be carried out immediately. Shi filed an appeal, stating that he had not committed murder. On 13 May, after trial in the Heilongjiang High People's Court, the court ruled that the original verdict relied on partially unclear facts and insufficient evidence, and so set aside the verdict and ordered a retrial. On 2 December 1991, the Yichun Municipal Intermediate People's Court again found Shi Dongyu guilty, but this time gave him a death penalty with two year suspension. On 7 December 1992, the intermediate court sent this verdict to the high court for review. The high court approved the verdict on 26 February. In 1995, the court declared Shi Dongyu not guilty by reason of having discovered the true perpetrator. See the news report: "I haven't killed anyone", Legal Daily, July 21, 1995; also see Guo Xinyang, Critical evaluations of wrongful convictions, the Publishing House of the People's Public Security University of China (Beijing), 2011, 213-217.

${ }^{23}$ On 22 April 1998, two officers of the Kunming public security bureau, in Yunnan Province, were shot - a particularly heinous crime. The investigation revealed a major suspect Du Peiwu, the husband of one of the victims. On 10 October, the Kunming Procuratorate issued an indictment to the Kunming Intermediate People's Court. On 5 February 1999, the Court sentenced Du Peiwu to death for the crime of murder. Du appealed to the Yunnan High People's Court, which, on 12 November 1999, issued a stay of execution. On June 14, 2000, Kunming Police arrested Yang Tianyong and associated gang members for crimes including murder and car theft, and discovered that it had actually been Yang and his gang who had killed the two police officers in April 1998 - a conclusion supported by material evidence including a gun, an ammunition magazine, and a microcassette recording. On 11 July 2000, the Yunnan Provincial High People's Court declared Du not guilty. See Guo Xinyang, Critical evaluations of wrongful convictions, the Publishing House of the People's Public Security University of China (Beijing), 2011, 140-152; also see the entry for "Du Peiwu" in Baidupedia http://baike.baidu.com.
}

outskirts of the city. Based on tips from the public, police identified Nie Shubin as a suspect and obtained a confession to the crime. On 15 March 1995, the Shijiazhuang Intermediate Court found the defendant Nie Shubin guilty of premeditated murder and sentenced him to death. They also found him guilty of rape and sentenced him to fifteen years in prison for that crime, with the primary evidence being his confession. On 25 April the High Provincial People's Court of Hebei released its final verdict approving the death sentence and two days later Nie Shubin was executed. $^{24}$

In March 2005, the alleged serial rapist, Wang Shujin, was arrested for other crimes, and while being interrogated confessed that he had raped and murdered a young woman in a cornfield by the side of the road on the outskirts of Shijiazhuang. His narration of the crime and knowledge of its location, which he identified, agreed with details of the rape-murder of the female surnamed Kang. Nie Shubin's mother had never believed that her son, who had always been an honest and timid boy, could have committed rape and murder, and so upon hearing this news made even more insistent appeals on her son's behalf, nevertheless to no avail. ${ }^{25}$ A police officer involved in the case said:

If this had happened ten years ago, we might well have determined Wang to be the murderer with only his confession to go on, and no other corroborating evidence. But cases can no longer be made with confession alone, not to mention this case has already been closed, and one person has been executed. $^{26}$

First of all, as for the interpretation of the 'definite error' rule, 'definite error' cannot be understood to mean that all the facts leading to a determination of guilt are incorrect, but rather that errors may exist in some of the facts. For example, in the case of Shi Dongyu the original verdict had been based on forensic testing of blood type to determine the traces of blood on the defendant's clothing to be that of the victim, Guan Zhuansheng. Later a second test showed the

\footnotetext{
${ }^{24}$ See Zhao Ling, 'A culprit with a conscience and court without: Nie Shubin's wrongful conviction', Southern Weekend, 2 November 2007.

${ }^{25}$ See Zhao Ling, 'Uncertain prospects for overturning the Nie Shubin case', Southern Weekend, 11 November 2009.

${ }^{26}$ See Zhou Xifeng, 'Wang Shujin, madman', Xiaoxiang Morning News, 7 March 2005.
} 
original test results to have been erroneous, and that the defendant's clothing had no blood from the victim on it. ${ }^{27}$ This is a determination of 'definite error'. This standard neither demands full and reliable evidence that Shi Dongyu was not the murderer nor did it require full and reliable evidence that Liang Baoyou was the murderer.

Second, Item (2) of Article 242, as stated above, stipulates that if: 'The evidence upon which the conviction was made and the punishment was meted out is unreliable or insufficient, or should be excluded according to law, or the major pieces of evidence for proving the facts in the case contradict each other.' The law certainly does not require reliable and sufficient evidence, but rather should be seen as holding to a standard of finding 'evidence either unreliable or insufficient'. This is similar to the 'formation of a reasonable doubt' standard of the USA and the UK, and also to the German 'overturn the intimate conviction' standard.

Finally, when using counter-evidence to prove that the claimant is not guilty, proving that another person is the true culprit certainly goes hand-in-hand with proving the conviction to be wrongful. The two standards are not equivalent. Excluding the possibility that the suspects committed the crime together, the probability that one of the two suspects committed the crime may go up or down. For example, in the Nie Shubin case, if the probability that Wang Shujin committed the murder and rape was 20 percent, then the chance that Nie Shubin committed the crime would have been 80 percent. And if Wang's odds reached 80 percent, then there would have been only a 20 percent chance that Nie could have been the perpetrator.

On 25 June 2013, the second-instance trial of Wang Shujin for rapes and murders finally began. Six years after Wang's shocking confession, the Hebei High People's Court tried the case again at the Handan Intermediate People's Court. The event garnered much public attention. Arguments in the retrial instigated a fresh outlook: the defendant maintained that he was indeed the true culprit Kang's case, while the prosecution making the charges maintained that he was not. Public attention focused not on whether Wang Shujin was guilty, but whether Nie Shubin was guilty.

\footnotetext{
${ }^{27}$ See He Jiahong and He Ran: Empirical Studies of Wrongful Convictions in Mainland China, Volume 80, No. 4, University of Cincinnati Law Review, Summer 2012, 1281.
}

In the courtroom on 25 June, the prosecution supplied four reasons why Wang Shujin could not have raped and murdered the victim surnamed Kang. First, Wang Shujin's testimony regarding the body did not correspond with the facts of the case. The corpse was clothed with a white undershirt; the neck had been obscured by corn stalks, which when removed, revealed that a flower-printed shirt. Wang Shujin's testimony lacked these details. Second, Wang's testimony as to the method of the murder did not correspond with the facts. The cause of death was strangulation, but Wang said he had first choked the victim, then stomped her on the chest until she died. But apart from the shirt wrapped around the victim's neck, there were no bone fractures found at the autopsy. Third, Wang's testimony as to the time of the victim's death did not accord with the facts. Fourth, Wang's description of the victim's height was incorrect. The prosecution also pointed out that, when the events occurred, Wang was at work at a factory nearby and familiar with the area around the crime scene, and when law enforcement authorities were examining the crime scene considerable numbers of public onlookers gathered around. In this way, Wang could have learned some of the details of the case in this way. ${ }^{28}$

So is Wang Shujin the true culprit, or not? We have no way of knowing. Based on the case presented by the prosecution, there is insufficient evidence to prove him guilty, or not guilty, or innocent. It is possible that he is lying - if, indeed, Wang could be so conniving; however, it is common for the actual criminal to make some errors when recounting the events of the crime - and it should be remembered that Wang's confession came more than ten years after the crime had been committed. Moreover, in the meantime he had committed rape and murder on three other occasions and rape on two other occasions. It would have been surprising if some of his testimony had not been confused and some of the details had not been mistaken, for his memory. In sum, given the evidence at hand, it cannot be certain that Wang Shujin committed the murder and rape of the victim surnamed Kang, nor can it be certain that he did not. Roughly, let us assume that chance Wang did commit the crime was about 60 percent. In other words, the chance that he is the true culprit is slightly higher than the chance he is not.

In the Chinese criminal procedure, the standard for proving a defendant guilty of a crime is that 'the facts of

\footnotetext{
${ }^{28}$ See the report by Lei Hongtao, June 26, 2013 in Legal weekly.
} 
the case are clear, the evidence reliable and sufficient'. In terms of probabilities, the chances that the defendant committed the crime must reach at least 90 percent. According the principle of presumption of innocence, or 'no conviction in a case of doubt', whenever the chances that the defendant is guilty drop below 90 percent the court should find the accused not guilty. In the case at hand, and if it can be assumed that Wang Shujin's chance of being the true culprit is only 60 percent, the court should find Wang 'not guilty' in the case of the rape and murder of the victim surnamed Kang. However, the next question is, what to do in the case of Nie Shubin? Some believe that Nie's case cannot be overturned as long as Wang Shujin cannot be identified as the true culprit. But not being able to confirm Wang Shujin as the true culprit is not equivalent to confirming Nie Shubin as the true culprit. When using counter-evidence to give indirect proof of wrongful conviction, an increased chance of one suspect committing the crime corresponds to a decreased chance that the other suspect had committed the crime. In this case, if there were a 60 percent chance that Wang Shujin committed the crime, and if this were not enough to determine his guilt, then Nie Shujin's 40 percent chance is also not enough to determine Nie's guilt.

On 27 January 2013, the Hebei High People's Court opened trial proceedings against Wang Shujin in the Handan Intermediate People's Court for the crimes of rape and murder. The court ruled that the evidence was insufficient to prove that Wang Shujin committed rape and murder against the victim surnamed Kang, and so rejected the appeal and re-affirmed the original verdict convicting him for other five charges of rape and murder. Wang Shujin was sentenced to death. ${ }^{29}$

On 12 December 2014, the Supreme People's Court of China made a decision to appoint the High People's Court of Shandong Province to review the case of Nie Shubin. On 28 April 2015, the High Court held a special hearing on the case, for which the Court invited 15 representatives of the people including law professors, journalists, members of the people's congress, and local residents. It is the first time for Chinese courts to hold such a hearing in a criminal case, and it may illustrate the direction of the related judicial reform. ${ }^{30}$ However, to the time of writing, people

\footnotetext{
${ }^{29}$ See Li Xianfeng, the Jinghua Times. 28 September 2013. At the time of writing, Wang Shujin's death sentence was being reviewed by the Supreme People's Court.

${ }^{30}$ See news report, 'Court's transparency in trial welcomed', China Daily, 30 April 2015.
}

are still waiting for the decision of Shandong High Court.

\section{CONCLUSION}

The rules regarding the standard for proving wrongful conviction in Chinese law are not clear enough and need to be enhanced with interpretation by relevant judicial agencies. It may be beneficial to learn from and perhaps incorporate aspects of the UK method of 'setting out the standards in levels', separated accordingly to redress wrongful convictions. The first standard relates to calling for a retrial or registering a wrongful conviction case, somewhat similar to the 'definite error' standard explained above, and similar in scope to the UK Criminal Cases Review Commission standard for sending cases up to the Appeals Court: 'possessing true potential to overturn the conviction'. The second level is the standard determining wrongful conviction in retrial, which can be formulated as 'preponderant evidence', meaning that the evidence in toto proves the probability the claimant is not guilty to be greater than the probability of guilt. The third level is the standard for determining state compensation, which can be formulated as 'evidence being reliable and sufficient', meaning that reliable evidence proves sufficiently that the claimant is indeed not guilty.

The standard of proof associated with determining state compensation should be higher than the standard of proof associated with determining a wrongful conviction. It is more appropriate. On the one hand, the application of the comparatively lower standard for proving wrongful conviction can give the innocent more chances for rectification. On the other hand, the application of a higher standard of proof for providing state compensation may prevent such compensation from becoming an obstacle to rectification. It will also reduce government expenditure associated with compensation, providing for the wiser use of taxpayer money.

Additionally, a system of accountability or liability of the parties involved in determining a wrongful conviction will raise the quality of the judiciary and lawenforcement, as well as the general morale of the legal profession. It can also, however, become an obstacle to rectification of wrongful conviction, and so the standards of accountability should be distinguished carefully from the standards for determining a wrongful conviction. In short, determining a wrongful conviction can follow the principle of 'no-fault liability', but 
determining the accountability of the people involved must follow the principle of 'fault liability'.

\section{ACKNOWLEDGEMENT}

The author hereby expresses his heartfelt thanks to Mr. Jesse Field who helped with some original translation from Chinese into English.

\section{REFERENCES}

Chen Ruihua, Criminal Procedure of Chinese Mode, China Law Press (Beijing), 2010.

Chen Weidong, ed., The Study of Countermeasures for Issues of Fact in Criminal Procedure, China Fangzheng Press (Beijing), 2002.

Ellen Hochstedler Steury and Nancy Frank, Criminal Court Process, translated by Chen Weidong \& Xu Meijun, China Renmin University Press (Beijing), 2002.
Fan Chongyi, ed., The Law of Criminal Procedure, the Publishing House of China University of Politics and Law (Beijing), 1999.

Guo Xinyang, Critical evaluations of wrongful convictions, the Publishing House of the People's Public Security University of China (Beijing), 2011.

He Jiahong and Zhang Weiping ed., Foreign Evidence Law Selected Translation (the second volume), People's Court Press (Beijing), 2000.

Liu Jinyou, ed. Evidence law, the Publishing House of China University of Politics and Law (Beijing), 2001.

Liu Pinxin, ed., Criminal Wrongful Conviction: Factors and Strategies, China Legal Publishing House (Beijing), 2009.

Mike McConville and Geoffrey Wilson, English criminal justice process, translated by Yao Yongji, the Law Press (Beijing), 2003.

Zuo Weimin, The Prospect of Criminal Procedure in China, SDX Joint Publishing Company (Beijing), 2010.

Received on 20-04-2015

Accepted on 30-04-2015

Published on 12-06-2015

DOI: http://dx.doi.org/10.6000/1929-4409.2015.04.10

(c) 2015 He Jiahong; Licensee Lifescience Global.

This is an open access article licensed under the terms of the Creative Commons Attribution Non-Commercial License (http://creativecommons.org/licenses/by-nc/3.0/) which permits unrestricted, non-commercial use, distribution and reproduction in any medium, provided the work is properly cited. 